\title{
18. TURBIDITE FACIES, ASSOCIATIONS, AND SEQUENCES IN THE SOUTHEASTERN ANGOLA BASIN ${ }^{1}$
}

\author{
Dorrik A. V. Stow, Grant Institute of Geology, University of Edinburgh, Edinburgh, Scotland, \\ EH9 3JW, United Kingdom
}

\begin{abstract}
Turbidite sedimentation occurred throughout the Cretaceous to Recent history of the Angola Basin but was particularly important in three discrete intervals of fan development. Three turbidite classes are identified: classical sandy turbidites (both volcanogenic and calcarenite types); silt and mud turbidites (including five types based on Stow turbidite divisions); and biogenic turbidites (both pelagic and calcilutite types). These various turbidites are best described and interpreted in terms of two related turbidite models (Bouma, 1962; Stow, 1977). Complete and partial sequences of each model can be interpreted in terms of depositional process and subenvironment. The composition of the sediment (sand, mud, biogenic, terrigenous, etc.) is found to play an important part in the nature of turbidites deposited.

Vertical facies sequences on the sandy volcanogenic "green fan" are interpreted as channel, lobe, and basin plain environments. For the muddy biogenic "brown fan," inner and outer fan and basin plain environments are more appropriate. Characteristic facies associations for each of these settings are described, based on facies types and proportions, turbidite frequency, bed thickness, grain size, and sedimentary structures. These associations are characteristic of open-ocean deep-water fans and basin plains and are significantly different from those described from land-based studies of ancient fans in small, more shallow-water, tectonically active basins.
\end{abstract}

\section{INTRODUCTION}

The sediment pile cored at Deep Sea Drilling Project (DSDP) Site 530 in the S.E. Angola Basin extends over the past 100 m.y. from late Albian time and is $1100 \mathrm{~m}$ thick (Figs. 1, 2). Core recovery was good (average $65 \%$ ), and I estimate that $20-30 \%$ of the sediments were deposited by turbidity currents, debris flows, and slumps. Mass gravity transport was most common during three separate periods (Campanian, MaestrichtianPalaeogene, and Miocene-Recent), corresponding to the three fan sequences described in another chapter (Stow, this volume), when they accounted for up to $60 \%$ of the sedimentation. Thin isolated turbidites occur throughout the rest of the section but rarely account for more than $5-10 \%$ of the deposits.

The regional and lithostratographic settings for turbidite sedimentation were described previously. This chapter outlines in more detail the characteristics of individual turbidites and sequences. Three broad groups or facies classes of turbidites are distinguished largely on the basis of grain size and composition:

1) Classical sandy turbidites-medium-grained sandstones and calcarenites;

2) Silt and mud turbidites-thin-bedded siltstones and mudstones;

3) Biogenic turbidites-variable-bedded muddy and biogenic deposits.

The debris flow deposits (debrites) are described in a separate chapter (Stow, this volume).

\footnotetext{
${ }^{1}$ Hay, W. W., Sibuet, J.-C., et al., Init. Repts. DSDP, 75: Washington (U.S. Govt. Printing Office).
}

\section{CLASSICAL SANDY TURBIDITES}

These turbidites occur in both the green and white fan sequences (lithologic Units 4-7). They are mediumcoarse-grained (or pebbly), medium-thick-bedded, and are best described in terms of the "classical" Bouma (1962) model for structural sequence in turbidites. Two types are recognized on compositional and other differences: volcanogenic sandstones and calcarenites.

\section{Volcanogenic Sandstones (Fig. 3, Plate 1)}

Thick-bedded volcanogenic turbidites (Fig. 3A) range from $30 \mathrm{~cm}$ to over $300 \mathrm{~cm}$ thick, and grade from medium-coarse sand size $(0.25-0.65 \mathrm{~mm})$ at the base to very fine sand size $(0.063 \mathrm{~mm})$ and finer at the top. The $\max -$ imum grain size at any one level is commonly one to two phi classes greater than the mean, so that the base of thicker beds is granular (maximum size $\sim 5 \mathrm{~mm}$ ). They are mostly poorly sorted, with angular to rounded sand grains and abundant clayey matrix. They show slight positive grading throughout, more marked towards the top; in some cases, there is a thin $(5-10 \mathrm{~cm})$ zone of reverse grading at the base and textural evidence of one or more amalgamation surfaces within individual layers.

Internal sedimentary structures closely follow the Bouma sequence (Fig. 3A). There is a sharp, commonly scoured base overlain sequentially by massive to graded A-division sandstone, faintly to well-laminated B-division, a thinner cross-laminated (more rarely convolutelaminated) $\mathrm{C}$-division, parallel silt-laminated $\mathrm{D}$-division mudstone, and massive or bioturbated E-division mudstone. Both base-cut-out (BCDE, BCE) and top-cut-out (ABCE, ABE) sequences are common (see Fig. 5). 


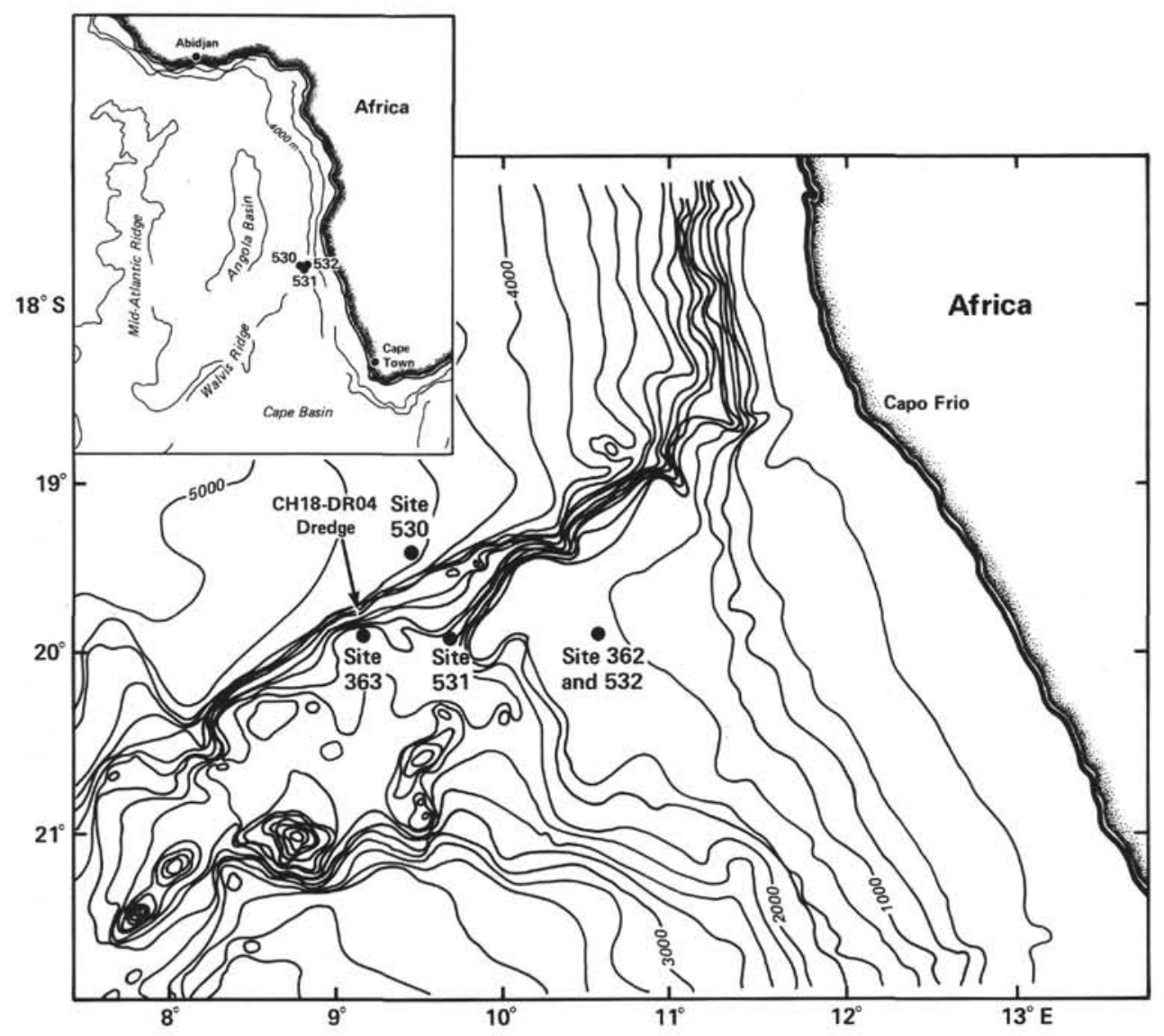

Figure 1. Location map and bathymetry of eastern Walvis Ridge and the adjacent southeastern Angola Basin. (Depth contours in $\mathrm{m}$ ).

Medium-bedded volcanogenic turbidites (Figs. 3B and $\mathrm{C}$ ), from $10-30 \mathrm{~cm}$ thick, grade from fine-medium sand size (0.15-0.35 mm, more rarely coarse) at the base to silt and mud size at the top. They are more distinctly graded than the thicker beds, but are poorly sorted and texturally immature with maximum grain sizes one or two phi classes greater than the mean. The Bouma sequence of internal structures is present, commonly as a base-cut-out sequence (BCDE, $\mathrm{BCE}, \mathrm{CDE})$ and with relatively thick development of the cross-laminated $\mathrm{C}$ division.

Compositionally, both the medium and thick-bedded turbidites are made up of dominantly volcanogenic detritus (glass, basalt, etc.) in various stages of alteration and devitrification to smectite clays. There is a variable admixture of carbonate, both as sparry or micritic cements and as partly recrystallized biogenic debris, and minor or accessory amounts of individual feldspars, pyroxenes, and other heavy mineral grains.

The thicker-bedded turbidites have a relatively uniform composition throughout, perhaps with slightly more carbonate and accessory minerals towards the base, and are uniformly greenish black in color. The medium-bedded turbidites have a similarly uniform volcanogenic/smectite composition, but commonly display striking color gradations from greenish sandstone at the base through bluish fine sandstone, purplish siltstone, reddish silty mudstone to brownish mudstone at the top
(Fig. 3B). Where carbonate forms a significant component, there is commonly a marked upward compositional gradation from more carbonate-rich at the base to less carbonate-rich (Fig. 3C). Internal lamination is also picked out by subtle variations in carbonate content.

\section{Calcarenites (Fig. 4, Plate 2)}

The calcarenite turbidites occur in beds up to about $65 \mathrm{~cm}$ thick (Figs. 4A and B). The thicker beds are coarse-grained (mean size, $0.5-2 \mathrm{~mm}$ ) pebbly calcarenites with clasts $10-15 \mathrm{~mm}$ in diameter (Fig. 4A). There is commonly a reverse-graded basal zone $10-15 \mathrm{~cm}$ thick overlain by a thick ungraded to slight positively graded middle zone and capped by a thin finer-grained calcarenite. Clasts are aligned parallel to bedding or more rarely imbricated, and beds are mostly parallel-laminated throughout, with or without a thin cross-laminated zone at the top. Lamination is picked out by compositional and grain-size differences (more or less carbonate-rich layers) and would seem to indicate that most of the thicker beds are Bouma B-division or BC turbidites.

The medium-bedded calcarenites (Fig. 4B) are more distinctly graded from pebbly or granular coarse sandsize (mean $0.5-1 \mathrm{~mm}$ ) at the base to fine sand-size $(0.063-0.15 \mathrm{~mm})$ at the top. They may also grade up into calcilutites and have a thin reversed-graded basal zone with a scoured base. B-division parallel lamination is the dominant structure, commonly overlain by cross- 


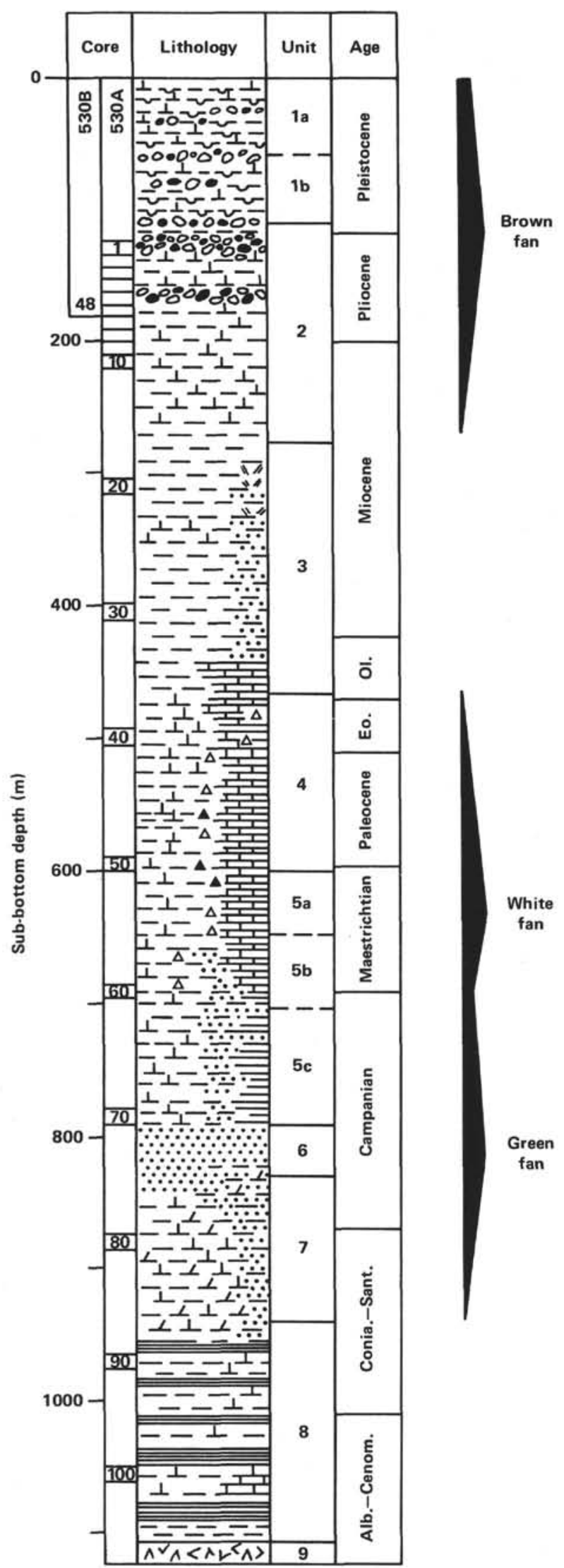

Figure 2. Stratigraphic and lithologic sequence at Site 530, Holes A and $\mathbf{B}$, showing the locations of the three fan sequences. (Revisions of stratigraphic ages are given in Steinmetz et al., this volume). lamination and, in some cases, by parallel-laminated, massive or bioturbated calcilutites, giving $\mathrm{BC}, \mathrm{BCE}$, and BCDE turbidites.

Carbonate forms $70-95 \%$ of the calcarenites, and in many cases it occurs mainly as recrystallized micritic and sparry calcite cement. A wide range of whole or partly recrystallized biogenics can also be identified, including planktonic and benthic foraminifers, bryozoans, algae, annelids, Inoceramus, and other molluscan debris. These indicate a mixing of shallow reefal and bathyal forms. Minor and trace components include volcanic debris, quartz, feldspar, heavy minerals, glauconite, and clays.

\section{SILT AND MUD TURBIDITES (Fig. 5, Plate 3)}

A wide variety of fine-grained turbidite types occur throughout the section cored at Site 530, in each of the three fan sequences and in all of the eight sedimentary lithologic units. They are for the most part fine-grained (fine sand to clay size), thin-bedded $(<10 \mathrm{~cm}$ thick), and show a range of sedimentary structures that are best described in terms of the Stow (1977) model for finegrained turbidites (Stow and Shanmugam, 1980). The thickest of these beds can also be described as base-cutout Bouma (1962) sequences or, in the case of the thicker mud turbidites, as Piper (1978) $\mathrm{E}_{1}-\mathrm{E}_{3}$ units.

Five distinct types are illustrated in Figures $5 \mathrm{~A}$ to $5 \mathrm{~F}$ and are described below.

\section{Complete Units ( $\left.\mathbf{T}_{0-8}\right)$ (Fig. 5A)}

Relatively complete sequences occur as graded laminated units from about 4 to $15 \mathrm{~cm}$ in thickness. These make up a basal layer or lamina $\left(\mathrm{T}_{0}\right)$, commonly with a scoured base, internal lamination, and fading-ripple top. This is overlain by lenticular laminae or low-amplitude ripples $\left(T_{2}\right)$, more rarely by convolute laminae $\left(T_{1}\right)$, and then by horizontal lamination $\left(\mathrm{T}_{3}\right)$, which becomes less distinct $\left(\mathrm{T}_{4}\right)$ and wispy $\left(\mathrm{T}_{5}\right)$ upwards. The overlying nonlaminated mud may be clearly graded $\left(T_{6}\right)$ or ungraded $\left(\mathrm{T}_{7}\right)$ and is bioturbated towards the top of the unit $\left(\mathrm{T}_{8}\right)$.

These units occur particularly near the base of lithologic Unit 8, where the silts are quartz-rich, and within the green fan (Units 5-7), where volcanogenic and carbonate silt and sand grains are more dominant. The grain size grades from fine sand or silt in the basal lamina through finer silt sizes in overlying laminae to clay size at the top. Color grading mirrors subtle compositional changes and is commonly more distinctive than size grading. This is particularly striking in some of the green fan turbidites that grade from green through hues of red, purple, and brown.

\section{Mid-Cut-Out Units $\left(T_{0678}, T_{048}\right)$ (Fig. 5B)}

In many cases the middle divisions of the complete structural sequence are missing, so that a well-developed basal silt layer is overlain directly by graded to bioturbated mud. The unit is commonly graded but nonlaminated although some thin silt laminae or indistinct laminae may be present immediately above the basal layer. The units are generally less than $5 \mathrm{~cm}$ thick. Grain 

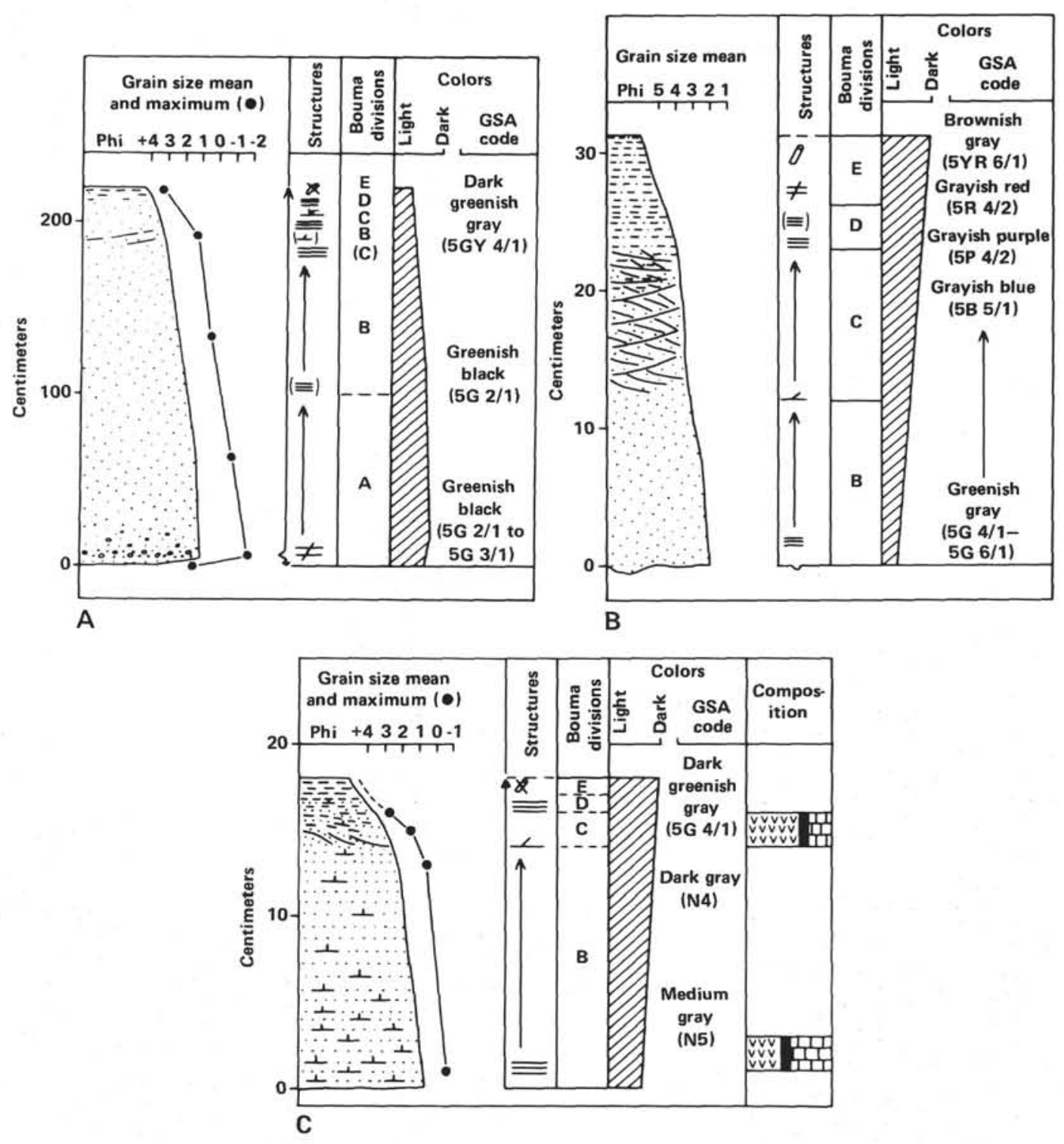

Figure 3. Sedimentary characteristics of volcanogenic sandstone turbidites: A, Thick-bedded; B, medium-bedded, C, mixed volcanogenic-calcarenitic. (See Fig. 10 for legend to sedimentary structures. Compare Plate 1.)

size, composition, and color changes are relatively abrupt from the silt to mud layers.

\section{Base-Cut-Out Laminated Units $\left(\mathbf{T}_{2-8}, \mathbf{T}_{4-8}\right)(\mathrm{Fig} .5 \mathrm{C})$}

Thin units (mostly $<5 \mathrm{~cm}$ thick) occur throughout, with the lower structural divisions missing. These begin with very low amplitude ripples, lenticular laminae, or horizontal silt laminae and are finer grained than either of the two types discussed above. Marked color gradations are common, but compositional changes are very subtle.

\section{Base-Cut-Out Nonlaminated Units $\left(\mathbf{T}_{4-8}, \mathbf{T}_{6-8}\right)$ (Fig. 5D)}

These are common throughout and similar to basecut-out laminated units in thickness and color grading. However, they are missing all but a single silt lamina at the base, and this too may be absent. They comprise predominantly graded, ungraded, and bioturbated muds and calcilutites. In Unit 2 they are commonly $10 \mathrm{~cm}$ and more in thickness and have large burrows throughout.

\section{Top-Cut-Out Units $\left(\mathbf{T}_{\mathbf{0 - 5}}, \mathrm{T}_{\mathbf{2 - 5}}\right)$ (Fig. 5E)}

There are a number of thin turbidites (commonly $<2$ $\mathrm{cm}$ thick) in which the top divisions are missing. Good examples occur in the green fan, where successive silty turbidites are very closely spaced and the nonlaminated and bioturbated mud divisions were either not developed or not preserved. Other examples, especially within the black shales (Unit 8), are finer-grained, equally or thinner bedded, and have both the basal and upper divisions missing. In these cases the topmost laminated divisions $\left(\mathrm{T}_{3}\right.$ or $\left.\mathrm{T}_{4}\right)$ are organic-carbon-rich mudstones without siltstone laminae but with a kerogen mud fissility, and so may not be "true" top-cut-out units.

Grain size analyses of several different fine-grained turbidites were carried out using an electric particle counter, and selected results are shown in Figure 6. Silt 


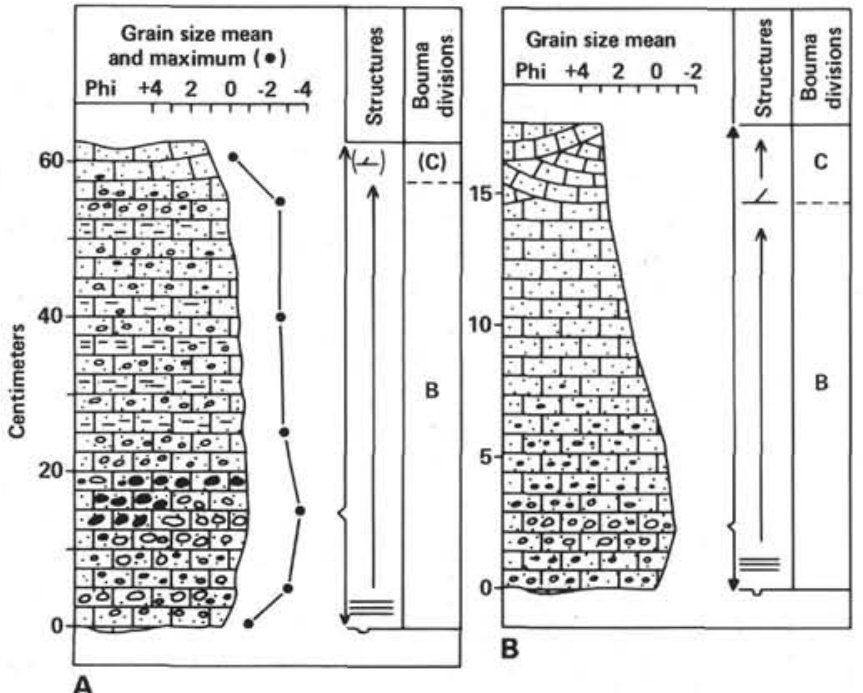

Figure 4. Sedimentary characteristics of calcarenite turbidites: A, thick-bedded pebbly calcarenite; B, medium-bedded. (See Fig. 10 for legend to sedimentary structures. Compare Plate 2.)

layers at the base of units are mostly well-sorted, having a distinct unimodal peaked frequency distribution with a small coarse tail and slightly larger fine tail. Very thin silt laminae as well as the diffuse-graded layers are less well sorted and less clearly unimodal. Mud layers, deflocculated for analysis, appear poorly sorted with relatively flat frequency distribution curves. The more silty muds at the base of graded mud turbidites have a marked coarse-fraction shoulder and small coarse tail. The overlying muds have a reduced or absent coarse shoulder and a much larger coarse tail. Size grading in these units can be very slight, and the results obtained in these analyses are very similar to those described for other fine-grained turbidites (for example, Piper, 1973; McCave, 1979).

\section{BIOGENIC TURBIDITES}

This distinctive group of turbidites occurs in both the brown and white fan sequences (lithologic Units 1, 2, and 4). They are dominantly fine grained, thin to thick bedded, and biogenic-rich. They can be described in terms of Stow's (1977) or Piper's (1978) fine-grained turbidite sequences, although the structural divisions are not so clearly defined as in the silt and mud turbidites discussed previously. Figure 7 shows examples from both the brown and white fans.

\section{Pelagic Turbidites (Figs. 7A and B, Plate 4)}

The turbidites in the brown fan range from very thick bedded (up to $1.5 \mathrm{~m}$ ) at the top to thin bedded near the base $(<10 \mathrm{~cm})$ of the succession. They have a sharp base, sometimes with a broad scour-like depression, a diffuse-graded horizontally laminated lower division passing up into an indistinctly laminated zone, and then graded and ungraded mud with bioturbation and burrows increasing upwards.

The laminated division varies from over $30 \mathrm{~cm}$ thick to a single basal lamina or may be completely absent.

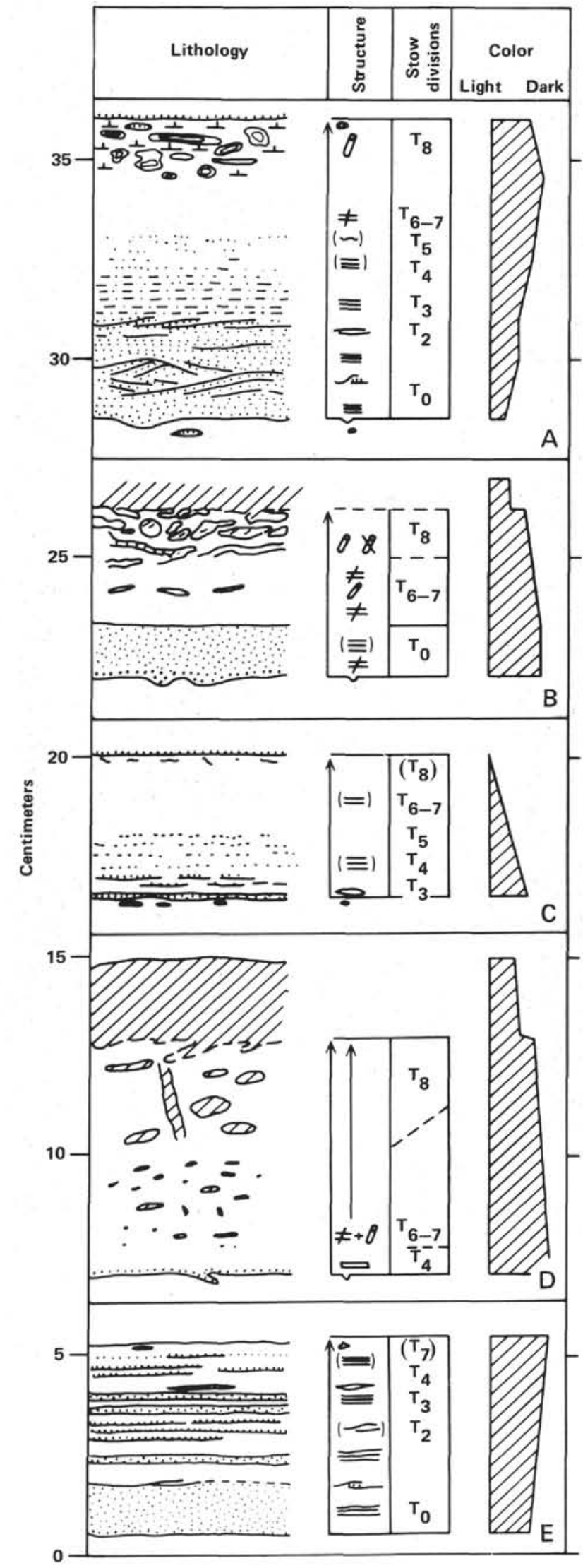

Figure 5. Sedimentary characteristics of silt and mud turbidites: A, complete; B, mid-cut-out; C, base-cut-out laminated; D, basecut-out nonlaminated; E, top-cut-out units. (See Fig. 10 for legend to sedimentary structures. Compare Plate 3.) 

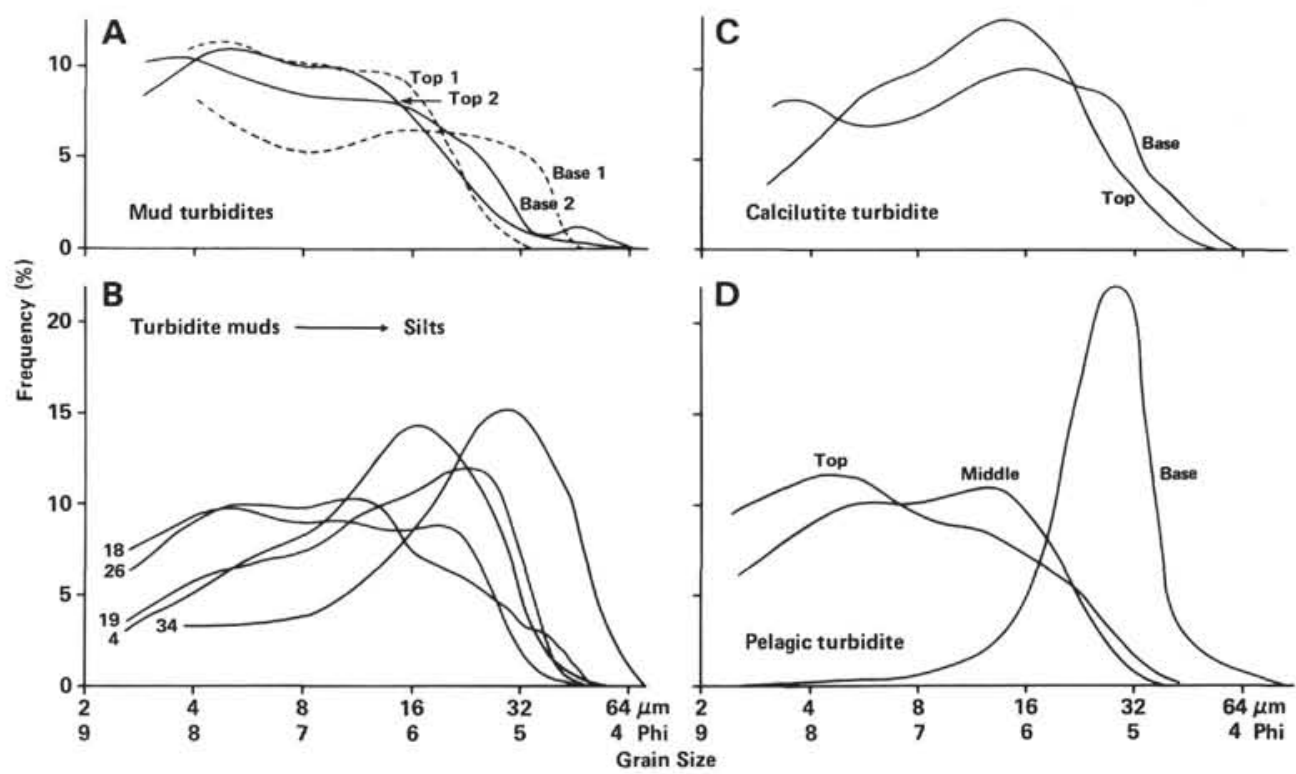

Figure 6. Smoothed grain-size histograms of characteristic fine-grained turbidites: A. mud turbidites, brown fan; B. silt-mud turbidites, brown and green fans; C. calcilutite turbidite, white fan; D. pelagic turbidite, brown fan.

The laminae are diffuse with gradational upper and lower contacts. Textural grading in the overlying mud division is very subtle where present, and it is not always possible to distinguish between graded and ungraded muds visually. Extensive bioturbation, reaching in some cases to more than $50 \mathrm{~cm}$ below the top of a turbidite bed, can further blur the contact between structural divisions.

The turbidites vary in composition from more biogenic rich near the top of Unit 1 to more clay rich towards the base of Unit 2 . The clay fraction is composed dominantly of illite with minor kaolinite, chlorite, and smectites. The biogenic components include mainly diatoms, nannofossils, and foraminifers in variable proportions, with siliceous microfossils being more abundant than calcareous between about 50 and $110 \mathrm{~m}$ depth (Unit 1b). Where the total biogenic fraction exceeds about $70 \%$ these are true ooze turbidites, and where it is less than $30 \%$ they are calcareous or siliceous mud turbidites. Most commonly, there are biogenic-mud mixtures between these extremes giving marl, sarl, and smarl turbidites.

Compositional grading within these turbidites is commonly more marked than textural changes. Foraminifers are concentrated with quartz-feldspar silts in the basal laminae and decrease in abundance upwards. Diatoms and nannofossils both increase upwards, whereas the clay content remains similar or shows a slight upward decrease. Color changes occur in parallel with these compositional variations, but both can be blurred by extensive bioturbation.

\section{Calcilutites (Figs. 7C and D, Plate 4)}

The coarser-grained biogenic turbidites of the white fan (calcarenites and calcirudites) were described in an earlier section. There are also very thin, thin, and medium-bedded $(1-20 \mathrm{~cm})$ calcilutites.
The thin-bedded calcilutites are similar to silt-mud turbidites with a basal calcisiltite-calcarenite layer overlain by fading-ripple lamination, horizontal lamination, and graded to bioturbated calcilutite. However, the lamination is not generally so distinct and is replaced by a more diffuse textural, compositional, and color grading. The middle divisions of the Stow sequence are commonly missing, giving $\mathrm{T}_{0678}, \mathrm{~T}_{048}$, and similar sequences.

The medium-bedded calcilutites are similar to the pelagic turbidites described above, although they often have a thin calcarenite-calcirudite basal layer. This is overlain by indistinctly laminated and graded to ungraded calcilutite with extensive bioturbation and burrowing increasing upwards.

\section{FACIES SEQUENCES AND ASSOCIATIONS}

\section{Green Fan Sequence}

The volcanogenic sandy turbidites and the silt-mud turbidites occur predominantly in the green fan (lithologic Units 5-7). As described in another chapter (Stow, this volume), there are thinning-upward and thickeningupward sequences that suggest deposition in channel, lobe, and basinal settings. The characteristic facies associations for each of these environments are shown in Figure 8 and will now be detailed.

Channel association (Figs. 8A, B, C). Turbidites account for $95-100 \%$ of the 40 -m thick main channel section. They are mainly thick to very-thick bedded (30$>300 \mathrm{~cm}$ ) and therefore average only one or two per meter of section. The thick turbidites are usually separated by thin-bedded sand-mud turbidites; only rarely are they separated by thin, bioturbated pelagic intervals (Bouma E division). The thick turbidites are coarse or medium-grained at the base and mud-grade at the top. Some $80-90 \%$ of the beds begin with either Bouma A or $B$ divisions and show various top-cut-out and mid-cut- 


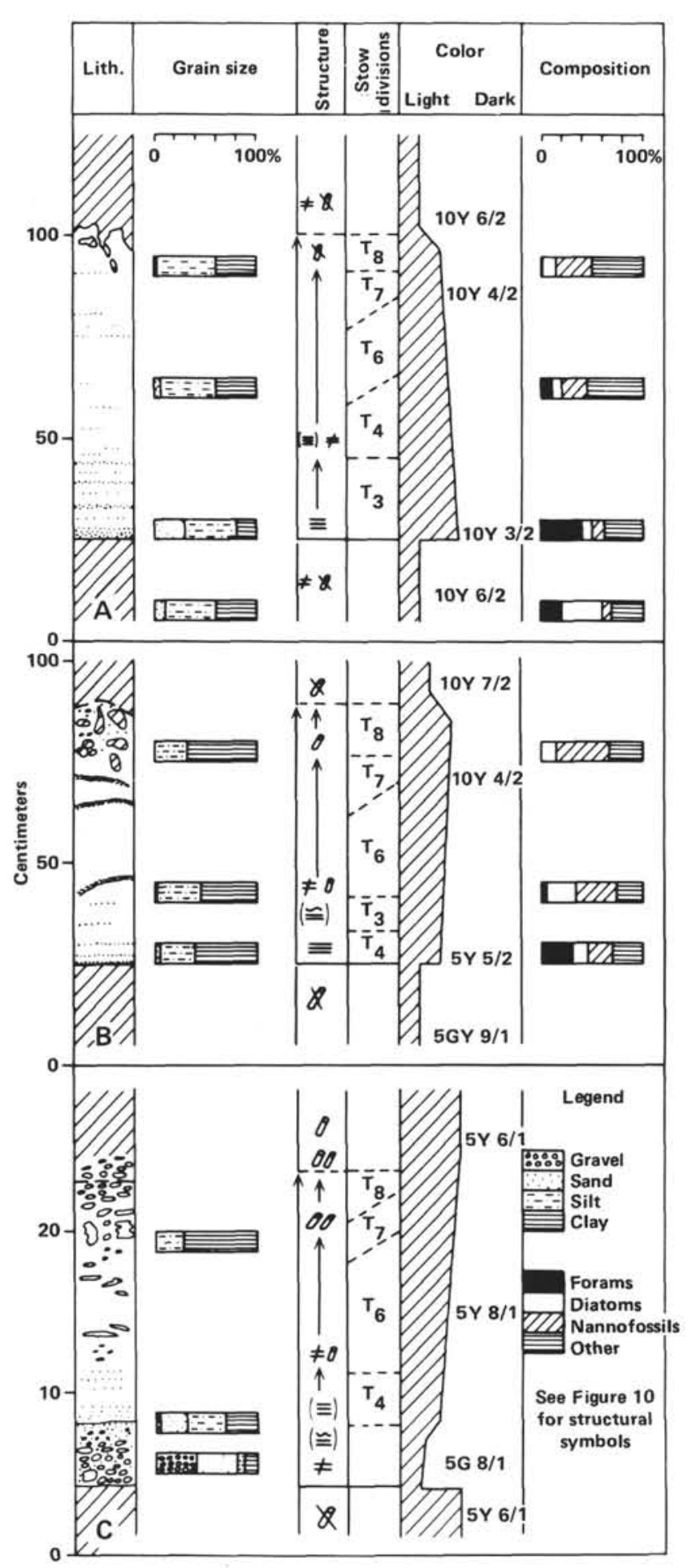

Figure 7. Sedimentary characteristics of biogenic turbidites: A and B, pelagic; C, calcilutite. (See Fig. 10 for legend to sedimentary structures. Compare Plate 4.)

out sequences. The remainder of the beds begin with Bouma C or D divisions.

There is no very regular arrangement of beds within the $40 \mathrm{~m}$ of main channel sands although a slight overall thinning-upwards is apparent. The channel-top association does, however, comprise progressively thinner and finer beds. Turbidites account for $50-60 \%$ of the section and average about 5 per meter. Fine and medium grade sands are common, and about $30 \%$ of the beds begin with each of Bouma B, C, and D divisions. Most show base-cut-out sequences.

The base of the channel is marked by a 2.5 -m-thick, coarse-grained Bouma $\mathrm{AB}(\mathrm{C}) \mathrm{E}$ turbidite that directly overlies a fine mudstone sequence containing very thin bedded $(<1-2 \mathrm{~cm})$ silt-mud turbidites. These are mostly very indistinct and the sequence considerably bioturbated, but the turbidites probably make up between 5 and $15 \%$ of the section and average about 20 per meter. Most are silt-sized at the base and begin with a Stow $T_{4}$ or $\mathrm{T}_{5}$ division. They are interbedded with isolated medium and thick-bedded turbidites and pass downwards into an interval with significant slumping.

Lobe association (Figs. 8D, E, F). The lobe-top association comprises interbedded thick- and thin-bedded turbidites and numerous slump horizons which together make up 50-60\% of the section and occur with variable frequency of 5 to 25 per meter. Turbidites are up to 40 $\mathrm{cm}$ thick, fine to medium grained, and range down through all thicknesses of silt-mud turbidites to very indistinct, thin silt laminae in a bioturbated mudstone facies. Slumps range from a few centimeters to over a meter in thickness and most commonly involve the finergrained sediments. The thicker-bedded turbidites begin with Bouma $\mathrm{B}$ or $\mathrm{C}$ divisions, and the thinner ones with Stow $\mathrm{T}_{0}-\mathrm{T}_{4}$ divisions. This very mixed lobe-top association probably represents shallow channelling across the top of a lobe prior to its abandonment.

The complete lobe sequence shows an overall thickening and coarsening-upward pattern over about 40-50 $\mathrm{m}$ within which there are smaller-scale irregular variations. Towards the top, turbidites comprise $40-60 \%$ of the section, are up to $30 \mathrm{~cm}$ thick, fine grained, and occur with a frequency of $8-10$ per meter. About $35 \%$ begin with Bouma $\mathrm{B}, \mathrm{C}$, or $\mathrm{D}$ divisions ( $\mathrm{C}$ being the most common), $40 \%$ with Stow $\mathrm{T}_{0}-\mathrm{T}_{2}$ divisions, and $23 \%$ with $\mathrm{T}_{3}-\mathrm{T}_{4}$ divisions. Towards the base, thin-bedded $(<10 \mathrm{~cm})$, very fine-grained turbidites make up only about $20-30 \%$ of the sediment with a frequency of 10-15 per meter. Bouma $\mathrm{C}$ and $\mathrm{D}$ division turbidites are less common, composing about $15 \%$ of the total; Stow $\mathrm{T}_{0}-\mathrm{T}_{2}$ divisions are just over $50 \%$ and $\mathrm{T}_{3}-\mathrm{T}_{4}$ about $40 \%$.

The lobe-fringe association comprises frequent (15-20 per meter) very thin and thin-bedded turbidites totalling only about $10 \%$ of the section. These are commonly indistinct siltstone laminae in an otherwise bioturbated hemipelagic mud. No classical Bouma sequence turbidites are present. It is not always possible to determine exactly which Stow division occurs at the base of each turbidite, but approximately $15 \%$ appear to begin with $\mathrm{T}_{0}-\mathrm{T}_{2}, 70 \%$ with $\mathrm{T}_{3}-\mathrm{T}_{4}$, and $15 \%$ with $\mathrm{T}_{5}-\mathrm{T}_{6}$.

Basin plain association (Fig. 8G, H). The $150 \mathrm{~m}$ of sediments (Unit 8) underlying the green fan were deposited in a relatively quiet basinal setting. They are composed of calcareous pelagic, hemipelagic, and turbiditic deposits, about $10 \%$ of which are sufficiently dark and fissile enough to be termed black shales. The turbidites are very fine grained (silt and mud size), very 


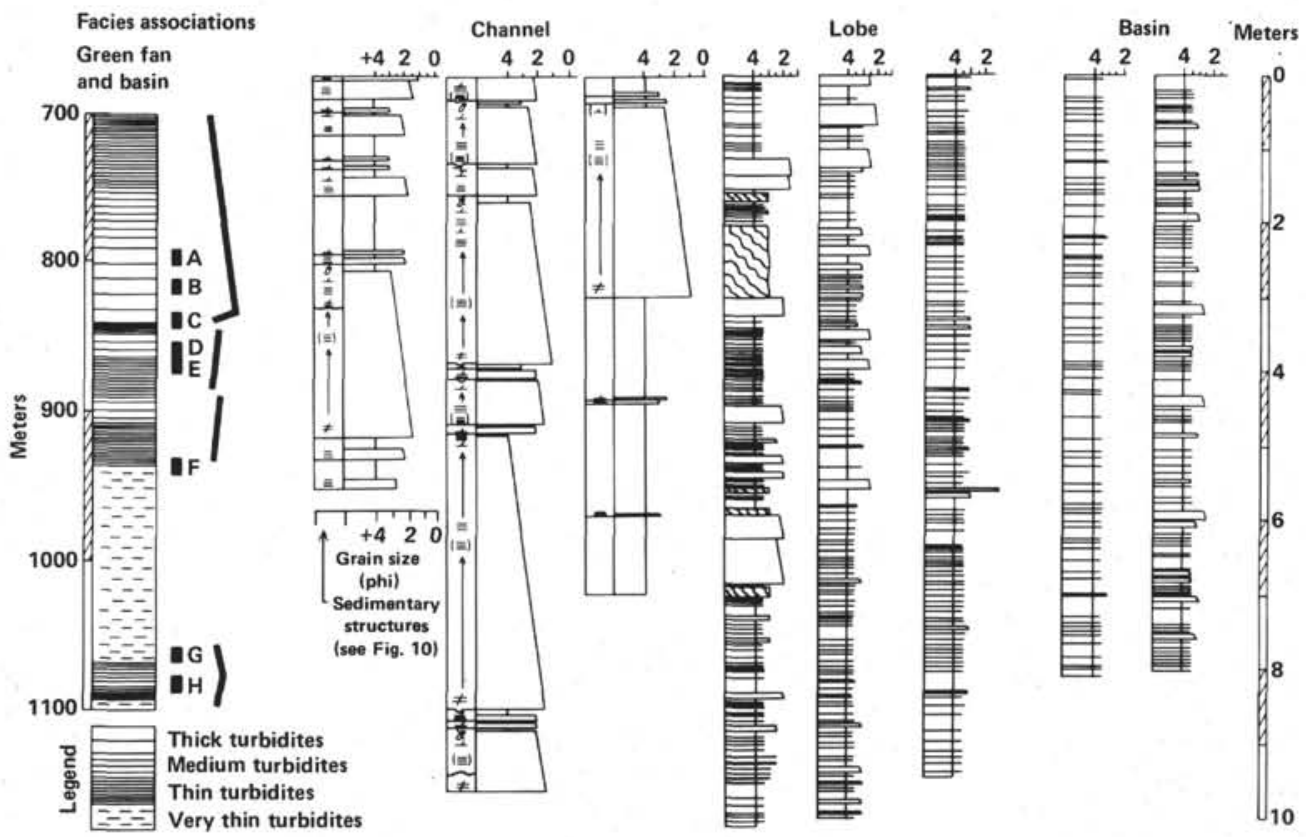

Figure 8. Facies association-lithologic column for the green fan-basin plain: A, B, C, channel; D, E, F, lobe; G, H, basin-plain associations.

thin bedded, and commonly disturbed by bioturbation, which makes their identification difficult. However, I estimate that, on average, about $10 \%$ of the section is made up of turbidites occurring with a frequency of 5-10 per meter. About $40 \%$ of these begin with Stow $\mathrm{T}_{3}-\mathrm{T}_{4}$ divisions and $40 \%$ with $\mathrm{T}_{5}-\mathrm{T}_{6}$ divisions.

There are no regular variations or sequences apparent through most of the basin plain facies, although smallscale ( $<1 \mathrm{~m}$ thick) rhythms similar to those reported by Shanmugam (1980) are present in parts. Towards the base of the section, however, there is a symmetrical coarsening and thickening sequence over about $25 \mathrm{~m}$. The turbidites are up to $15 \mathrm{~cm}$ thick, make up $25-30 \%$ of the sediments, and occur with a frequency of 10-15 per meter. There may be a few $(\sim 5 \%)$ Bouma sequence turbidites (divisions $\mathrm{C}$ and $\mathrm{D}$ ), but most begin with Stow $\mathrm{T}_{0}-\mathrm{T}_{2}(\sim 20 \%), \mathrm{T}_{3}-\mathrm{T}_{4}(\sim 40 \%)$, and $\mathrm{T}_{5}-\mathrm{T}_{7}(\sim 35 \%)$ divisions. This symmetrical sequence is interpreted as an isolated basin-lobe association, probably with no direct connection to a submarine fan.

\section{Brown Fan Sequence}

The pelagic ooze and mud turbidites occur predominantly in the brown fan (lithologic Units 1 and 2), in association with debris-flow deposits. This fan is morphologically distinct and, presumably, is presently active at the present day (Stow, this volume). However, classical channel and lobe sequences are not recognized and may not exist in the same way as on coarser siliciclastic fans. Instead, inner and outer fan and underlying basin-plain facies associations can be characterized (Fig. 9).

Inner fan association (Figs. 9A, B, C). The topmost $150-180 \mathrm{~m}$ of sediments at Site 530 can be considered an inner fan association. This comprises about $30 \%$ slump deposits, $30 \%$ debrites, $15-20 \%$ turbidites, and $20-25 \%$ pelagites. However, the distribution of these facies is very irregular, with very thick slumps and debrites in the lower part, the rest being interbedded turbidites, pelagites, and thin debrites in variable proportions. The turbidites are thick to very thick bedded $(20-150 \mathrm{~cm})$ and occur with a frequency of less than one per meter. They are both calcareous and siliceous biogenic-rich muds, oozes, smarls, etc., for the most part but commonly with a biogenic sand fraction near the base of units. These turbidite units begin with a laminated division (Stow $\mathrm{T}_{3}-\mathrm{T}_{4}$, Piper $\mathrm{E}_{1}$ ) or with a graded nonlaminated division (Stow $\mathrm{T}_{6}$, Piper $\mathrm{E}_{2}$ ) and pass upwards into an extensively bioturbated, ungraded division.

Outer fan association (Fig. 9D, E). There is an overall upward increase in turbidite bed thickness and in the frequency of debrites over the lower $100 \mathrm{~m}$ or more of the brown fan. This thickening and coarsening-upward sequence is interpreted here as a prograding outer fan rather than lobe sequence, although the distinction is, perhaps, a blurred one. Towards the top of the outerfan sequence, the turbidites are up to $40 \mathrm{~cm}$ thick, compose about $20 \%$ of the sediment, and occur with a frequency of 2-3 per meter. Debrites can be over $2 \mathrm{~m}$ thick; they can make up about $20 \%$ of the section, but usually occur less frequently. Towards the base the turbidites are thinner bedded (up to about $20 \mathrm{~cm}$ ) and more common (5-6 per meter), composing some $25-30 \%$ of the sediment. Debrites are thinner bedded and infrequent.

The turbidites are biogenic muds with quartz-rich silt laminae, becoming more terrigenous (clay-rich) in composition down section. Some units $(35-40 \%)$ begin with a thin silt-laminated basal division (Stow $\mathrm{T}_{3}-\mathrm{T}_{4}$, Piper $\left.E_{1}\right)$, whereas rather more $(60-65 \%)$ begin with graded or ungraded nonlaminated muds (Stow $\mathrm{T}_{5}-\mathrm{T}_{7}$, Piper $\mathrm{E}_{2}$ $\mathrm{E}_{3}$ ) and are commonly bioturbated throughout.

Basin plain association (Figs. 9F, G). Lithologic Unit 3 , directly underlying the brown fan sequence, comprises $190 \mathrm{~m}$ of carbonate-free, red and green pelagic muds, 


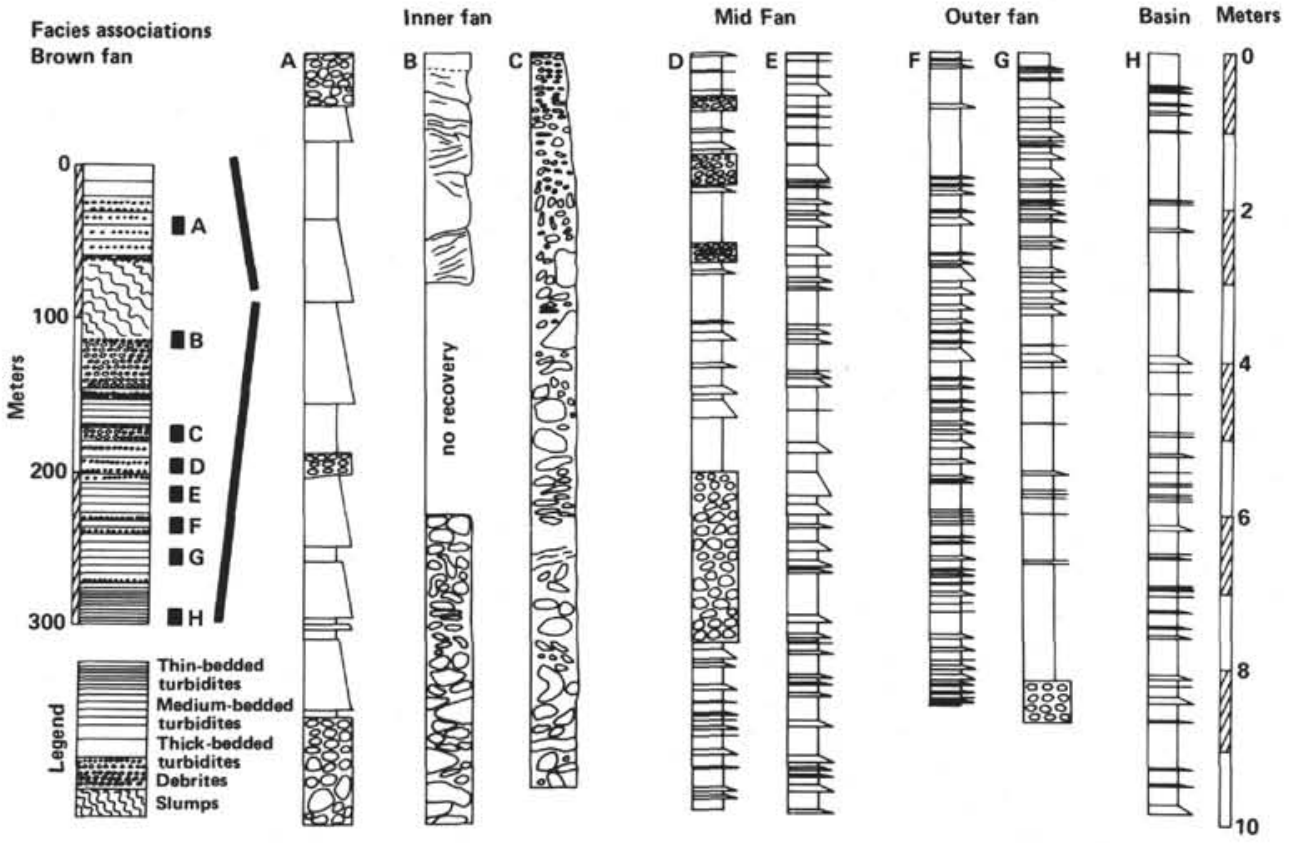

Figure 9. Facies association-lithologic column for the brown fan-basin plain: A, B, C, inner fan; D, E, outer fan; F, G, basin-plain associations.

irregularly interbedded with rare, thin, mud turbidites and volcanogenic horizons. These sediments were deposited in the Oligocene-Miocene basin into which the brown fan prograded. The turbidites make up only $4-8 \%$ of the section and are relatively infrequent $(2-3$ per meter). They are mostly very thin-bedded $(<3 \mathrm{~cm})$, but may be up to $12 \mathrm{~cm}$ thick, and are commonly disturbed by bioturbation. It is therefore difficult to recognize structural sequences; thin silt laminae are present at the base of some units (Stow $\mathrm{T}_{3}-\mathrm{T}_{4}$ divisions), whereas others are simply graded to bioturbated muds (Stow $\mathrm{T}_{5}-\mathrm{T}_{7}$ divisions.)

\section{White Fan Sequence}

The calcarenite and calcilutite turbidites occur throughout the white fan sequence (lithologic Units 4 and part of 5). There is some evidence of thinning-upward and thickening-upward sequences (Stow, this volume), but core recovery is insufficient to determine characteristic facies associations.

\section{DISCUSSION}

\section{Turbidite Models}

Two different turbidite models (Fig. 10) were found to be most useful in describing and interpreting the mass gravity flow deposits cored at Site 530. The "classical" Bouma model (Bouma, 1962) is applicable to the sandy volcanogenic and calcarenite turbidites, and the Stow model (Stow, 1977, Stow and Shanmugam, 1980) is more appropriate for the fine-grained silt-mud and biogenic turbidites. There is continuum of sedimentary characteristics between the thicker-bedded, coarsergrained Bouma-type turbidites and the thinner-bedded,
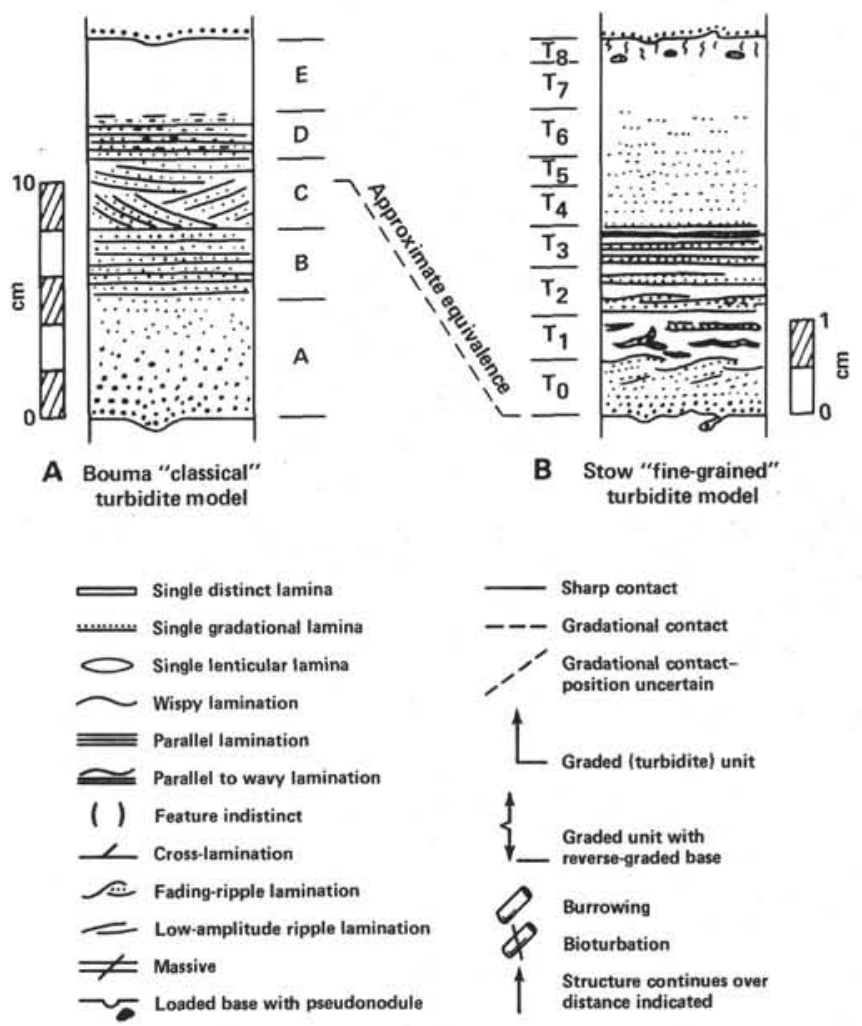

Figure 10. Turbidite models and legend.

finer-grained Stow-type turbidites that is related principally to turbidity current transport and to sediment type. The Piper (1978) model for fine-grained turbidites is also applicable, but is contained in the more detailed 
Stow model. No very coarse-grained sediments were encountered, apart from debris-flow deposits, which are discussed in a separate paper (Stow, this volume).

Thin-bedded silt and mud turbidites are ubiquitous throughout the cored section. They are similar to those described by Piper (1978), Nelson et al. (1978), Stow (1979), and Stow and Shanmugan (1980) among others, and to the very many reports of fine-grained turbidites documented at other DSDP sites (see summary by Kelts and Arthur, 1981). These examples are mainly from other open ocean settings, where the five basic types of unit distinguished at Site 530 can also be identified.

Complete units are relatively rare, and presumably result from fully developed, mature, thick, turbidity currents in a depositional phase after a medium to long flow distance that has allowed adequate hydrodynamic evolution. Base-cut-out laminated and nonlaminated units are progressively more distal, either downslope or across-slope by turbidity current overflow into levee and interchannel environments. The basal divisions have either been deposited upslope or have remained in the channelized portion of the current. Mid-cut-out and top-cut-out units were both deposited in the more proximal parts of flows. The former may result from an incompletely evolved turbidity current, and the latter from a high frequency of currents coupled with erosion of the upper divisions. The absence of only one or two divisions from any of these units is common and most likely results from the complex interplay of velocity, concentration, and sediment type within a depositing turbidity current.

Careful documentation of the characteristics and variation of silt and mud turbidites is important for correct interpretation of the depositional process and environment (e.g., Piper, 1978; Nelson et al., 1978; Stow, 1981; Stow et al., in press).

Biogenic turbidites are also an important class of ocean sediments, although requiring a more specific environment of deposition than the siliclastic silt and mud turbidites (von Stackelberg, 1979; Crevello and Schlager, 1980; Orwig, 1981; Faugeres et al., in press). Kelts and Arthur (1981) summarize the many examples recorded from other DSDP sites to date.

The medium and thick-bedded pelagic turbidites cored at Site 530 show less well-defined structural sequences and more diffuse grading than do the thin-bedded siltmud turbidites. The calcilutites are also distinctly different. In both cases it is suggested that these differences result partly from the differences in hydrodynamic and flocculating properties of biogenic and terrigenous materials. However, in some cases the biogenic content is relatively minor in comparison to the terrigenous clay fraction, and these mud turbidites are very similar to the thick, graded, structureless to faintly laminated unifites described from eastern Mediterranean basin plains (Stanley and Maldonado, 1981; Blandpied and Stanley, 1981).

A uniform fine-grained sediment source for the redepositing turbidity currents would also favor homogeneity rather than distinct structural divisions.

\section{Sequences and Association}

Vertical facies sequences of the green fan and underlying sediments can be interpreted in terms of channel, lobe, and basin plain depositional environments (Mutti and Ricci Lucchi, 1972; Walker and Mutti, 1973; Rupke, 1978; Walker, 1978). Diagnostic features, in addition to the vertical sequence, include the facies types and their proportion of the section, turbidite frequency, bed thickness, sediment size, and sedimentary structures.

The Walker (1967) proximality index is only applicable to the channel association, the other environments being too distal. In these cases an indication of proximality is better provided by the relative number Boumatype (CDE etc) to Stow-type $\left(\mathrm{T}_{0-8}\right)$ turbidites, and the relative numbers of turbidites beginning with Stow basal divisions $\left(\mathrm{T}_{012}\right)$, middle divisions $\left(\mathrm{T}_{34}\right)$, and upper divisions $\left(\mathrm{T}_{567}\right)$.

For the brown fan and underlying section, characteristic channel and lobe sequences are not apparent. Such muddy biogenic fans may not develop the channelized morphology typical of siliclastic and coarser biogenic fans, perhaps because fine biogenic material is less susceptible to channeling or tends to form more diffuse turbidity flows. However, an inferred progradational sequence can be recognized from basin plain through outer fan to inner fan. Similar diagnostic features as for the green fan are applicable in this case.

These turbidite sequences and associations are believed to be characteristic of open-ocean deep-water fan and basin plain evnironments. The brown fan is relatively small (radius about $30 \mathrm{~km}$ ); the green fan may have been larger but certainly not large by oceanic standards. In both cases, however, there are very significant differences from the facies sequences and associations described from small and medium-sized ancient fans. Although the general sequences for the green fan are similar to those described by Mutti and Ricci Lucchi (1972), Mutti (1977), Ricci Lucchi (1978), Walker (1978), and Pickering (1981, 1982) among others, these land-based studies reveal much more proximal characteristics in even the more distal fan and basin-plain environments. Ricci Lucchi and Valmori (1980), for example, describe a deep-sea basin-plain association with $80-90 \%$ turbidites, $50 \%$ sandstone, and $40 \%$ of the turbidites thicker than $40 \mathrm{~cm}$. Pickering (1981) describes lobe deposits with very thick to medium-bedded, very coarse to medium-grained sandstone turbidites composing more than $80 \%$ of the section, and having Bouma ABC structural divisions. Contrast these with the green fan lobes $(20-50 \%$ turbidites, thin bedded, fine to very fine grained, Bouma CDE and Stow-type structural divisions) or basin-plain deposits $(<10 \%$ turbidites, silt, and mud grade only).

Similarly, the depositional models proposed for finegrained sediments in the eastern Mediterranean (Stanley and Maldonado, 1981; Feldhausen et al., 1981) place the thick muddy "unifites" in the most distal basinplain setting, whereas the equivalent brown fan deposits 
(thick biogenic turbidites) represent a relatively proximal inner fan environment.

Both the land-based and marine-based studies are well documented and the respective interpretations do not appear to be in error. It is very important, therefore, to be aware of differences between sedimentation in the open ocean and in small basins when constructing and applying fan models in sedimentology. The most distal deposits of a small, shallow-water, tectonically active basin may be similar in many respects to the most proximal deposits of a medium-sized, deep-water, passive margin fan.

\section{ACKNOWLEDGMENTS}

DAVS acknowledges personal support from the Natural Environment Research Council, U.K. He would also like to thank the secretarial and technical staff at the Grant Institute of Geology, and Drs. A. H. F. Robertson and K. T. Pickering for their helpful comments.

\section{REFERENCES}

Blanpied, C., and Stanley, D. J., 1981. Uniform mud (unifite) deposition in the Helenic Trench, eastern Mediterranean. Smithson. Contrib. Mar. Sci., 13:40.

Bouma, A. H., 1962. Sedimentology of Some Flysch Deposits: Amsterdam (Elsevier).

Crevello, P. D., and Schlager, W., 1980. Carbonate debris sheets and turbidites, Exuma Sound, Bahamas. J. Sediment. Petrol., 50: 1121-1148.

Faugeres, J. C., Gayet, J., Gonthier, E., Poutiers, J., and Nyang, I., in press. La dosale medio-atlantique entre $43^{\circ}$ and $56^{\circ} \mathrm{N}$. Facies et dynamique sedimentaire dans plusieurs types d'environements au Quaternaire recent. Inst. Geol Bassin Acquitaine, Bull.

Feldhausen, P. J., Stanley, D. J., Knight, R. J., and Maldonado, A., 1981. Homogenization of gravity-emplaced muds and unifites: Models from the Hellenic Trench. In Wezel, F. C. (Ed.), Sedimentary Basins of Mediterranean Margins, CNR Italian Project of Oceanography, Technoprint, Bologna, pp. 203-226.

Kelts, K., and Arthur, M. A., 1981. Turbidites after ten years of deep-sea drilling-wringing out the map? Soc. Econ. Paleontol. Mineral., Spec. Publ., 32:91-127.

McCave, I. N., 1979. Diagnosis of turbidites at Sites 386 and 387 by particle-counter size analysis of the silt $(2-40 \mu \mathrm{m})$ fraction. In Tucholke, B. E., Vogt, P. R., et al., Init. Repts. DSDP, 43: Washington (U.S. Govt. Printing Office, Washington), 395-405.

Mutti, E., 1977. Distinctive thin-bedded turbidite facies and related depositional environments in the Eocene Hecho Group (Southcentral Pyrenees, Spain. Sedimentology, 24:107-131.

Mutti, E., and Ricci Lucchi, F., 1972. Le torbiditi del' Appenino settentrionale: Introduzione all' analisi di facies. Soc. Geol. Ital., 11: 161-199.

Nelson, C. H., Normark, W. R., Bouma, A. H., and Carlson, P. R., 1978. Thin-bedded turbidites in modern submarine canyons and fans. In Stanley, D. J., and Kelling G. (Eds.), Sedimentation in Submarine Canyons, Fans and trenches: Stroudsberg, Penn. (Dowden, Hutchinson and Ross), pp. 177-189.
Orwig, T. L., 1981. Channeled turbidites in the eastern central Pacific basin. Mar. Geol., 39:33-57.

Pickering, K. T., 1981. Two types of outer fan lobe sequence from the late Precambrian Kongsfjord formation submarine fan, Finnmark, North Norway. J. Sediment Petrol., 51:1277-1286. , 1982. The Kongsfjord Formation-A late Precambrian submarine fan in N.E. Finnmark, N. Norway. Nor. Geol. Unders.

Piper, D. J. W., 1973. The sedimentology of silt turbidites from the Gulf of Alaska. In Kulm, L. D., von Huene, R., et al., Init. Repts. $D S D P, 18$ : Washington (U.S. Govt. Printing Office, Washington), 847-867.

1978. Turbidites, muds and silts on deep-sea fans and abyssal plains. In Stanley, D. J., and Kelling, G. (Eds.), Sedimentation in Submarine Canyons, Fans and Trenches: Stroudsberg, Penn. (Dowden, Hutchinson and Ross), pp. 163-176.

Ricci Lucchi, F. R., 1978. Turbidite dispersal in a Miocene deep-sea plain: The Marnoso-Arenacea of the Northern Apennines. Geol. Mijnbouw, 57:559-576.

Ricci Lucchi, F., and Valmori, E., 1980. Basin-wide turbidites in a Miocene, over-supplied deep-sea plain: A geometrical analysis. Sedimentology, 27:421-270.

Rupke, N. A., 1978. Deep clastic sear. In Reading, H. G. (Ed.), Sedimentary Environments and Facies: (Blackwell), pp. 372-395.

Shanmugam, G., 1980. Rhythms in deep sea, fine-grained turbidite and debris-flow sequences, middle Ordovician, eastern Tennessee. Sedimentology, 27:419-432.

Stanley, D. J., and Maldonado, A., 1981. Depositional models for fine-grained sediment in the western Hellenic Trench, eastern Mediterranean. Sedimentology, 28:273-290.

Stow, D. A. V., 1977. Late Quaternary stratigraphy and sedimentation on the Nova Scotian outer continental margin [Ph.D. dissert.]. Dalhousie University, Canada.

1979. Distinguishing between fine-grained turbidites and contourites on the Nova Scotian deep water margin. Sedimentology, 26:371-387.

1981. Laurentian Fan: Morphology, sediments, processes and growth pattern. AAPG Bull., 65:375-393.

Stow, D. A. V., Bishop, C. D., and Mills S. J., in press. Sedimentology of the Brae Oil Field, North Sea: Fan models and controls. J. Petrol. Geol.

Stow, D. A. V., and Shanmugam, G., 1980. Sequence of structures in fine-grained turbidites: Comparison of recent deep-sea and ancient flysch sediments. Sediment. Geol. 25:23-42.

von Stackelberg, U., von Rad, U., and Zobel, B., 1979. Asymmetric sedimentation around Great Meteor Seamont (North Atlantic). Mar. Geol., 33:117-132.

Walker, R. G., 1978. Deep water sandstone facies and ancient submarine fans: Models for exploration for stratigraphic traps. Bull. Am. Assoc. Petrol. Geol., 62:932-966.

Walker, R. G., 1967. Turbidite sedimentary structures and their relationship to proximal and distal depositional environments. J. Sediment Petrol., 37:25-43.

Walker, R. G., and Mutti, E., 1973. Turbidite facies and facies associations. In Middleton, G. V., and Bouma, A. H. (Eds.), Turbidites and Deep Water Sedimentation, SEPM Pacific Section Short Course, Anaheim (1973), pp. 119-158.

Date of Initial Receipt: October 15, 1982 

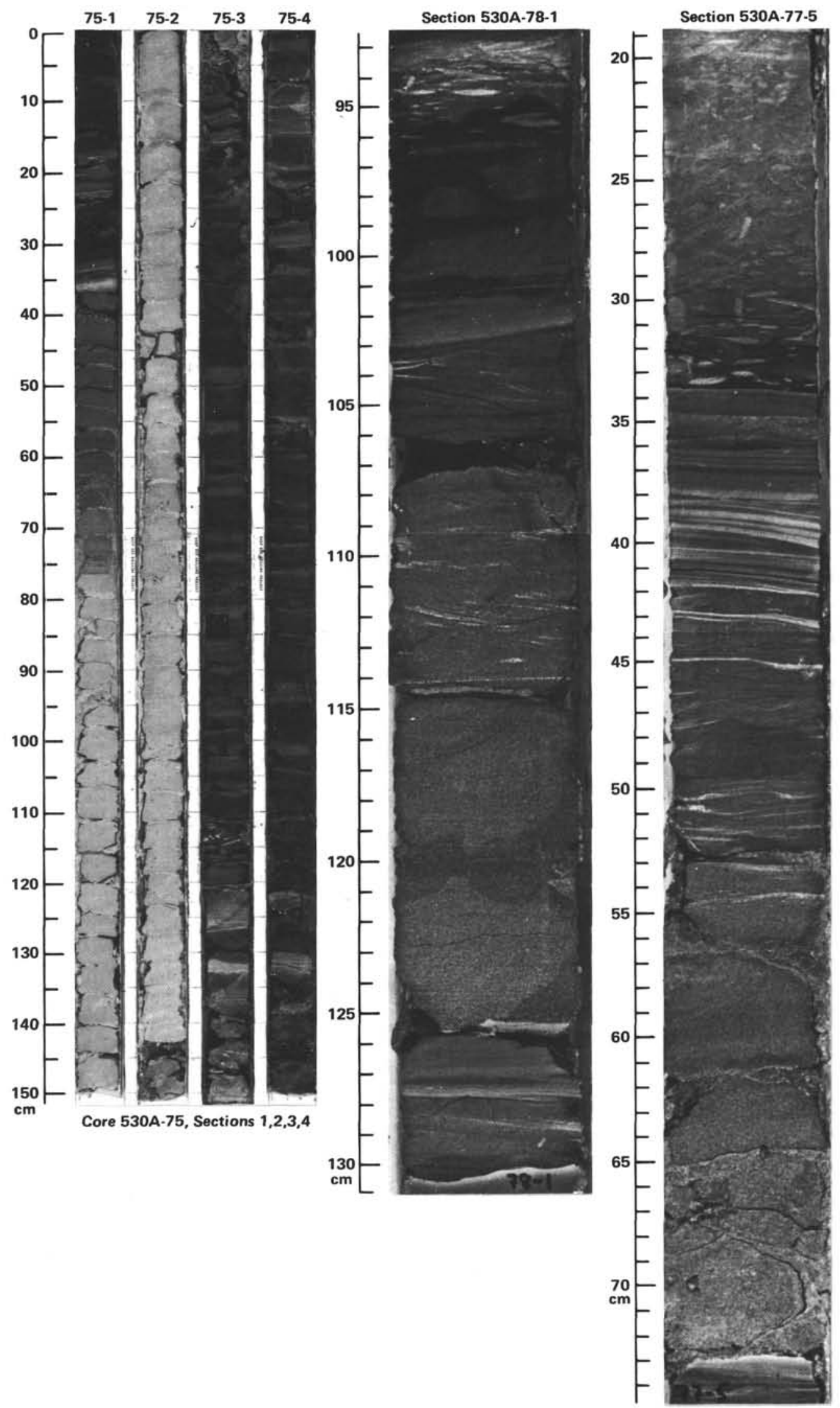

Plate 1. Volcanogenic sandstone turbidites. (Scale in $\mathrm{cm}$.) Left: thick turbidite at base of channel sequence overlying fine-grained interchannel deposits. Center and right: Detail of two examples of medium-bedded turbidites showing clear grading and Bouma structural sequences. 


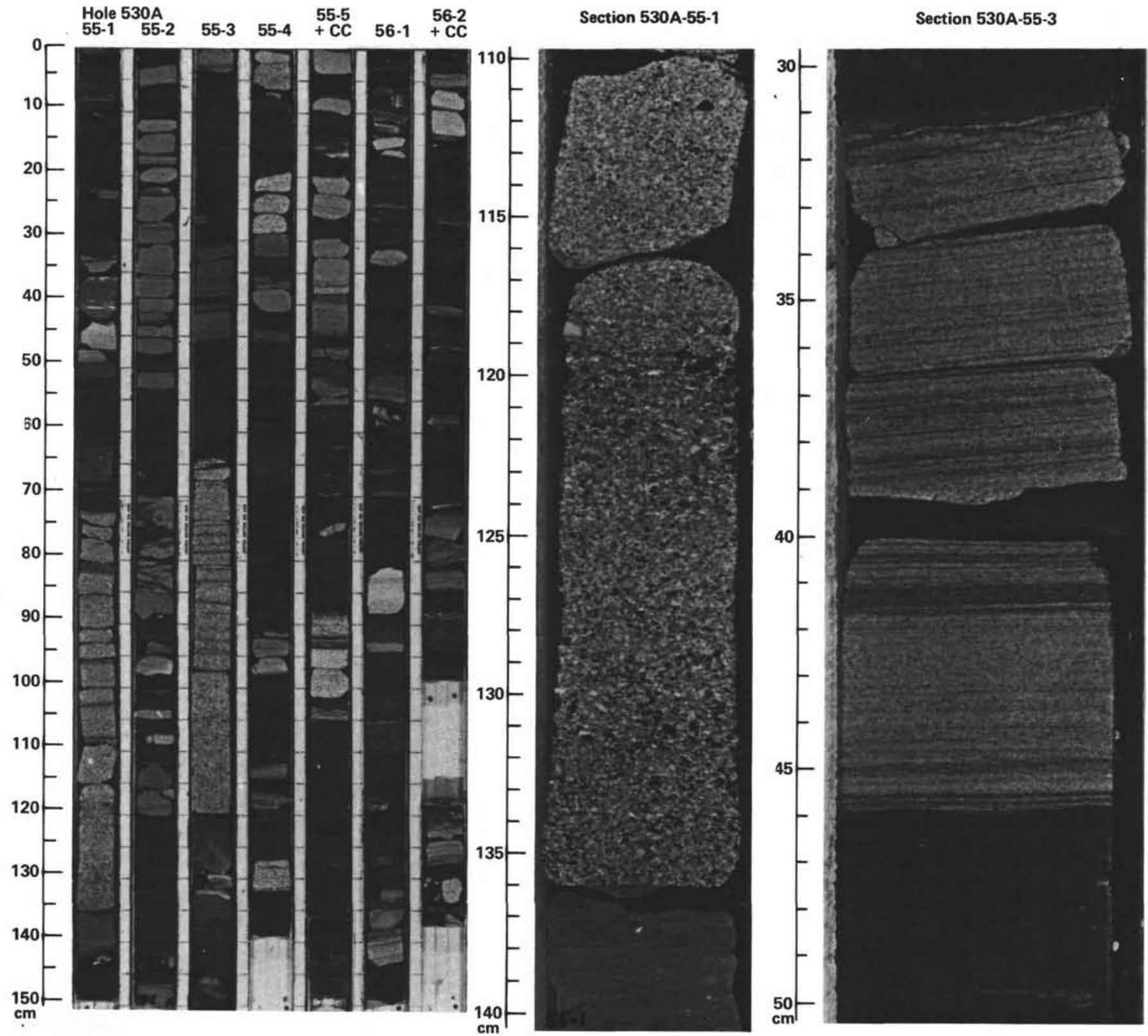

Plate 2. Calcarenite turbidites. (Scale in $\mathrm{cm}$.) Left: Thin to thick-bedded turbidites (light) interbedded with mudstone and marlstone (dark). Center and right: Detail of graded pebbly-calcarenite and parallel-laminated calcarenite. 

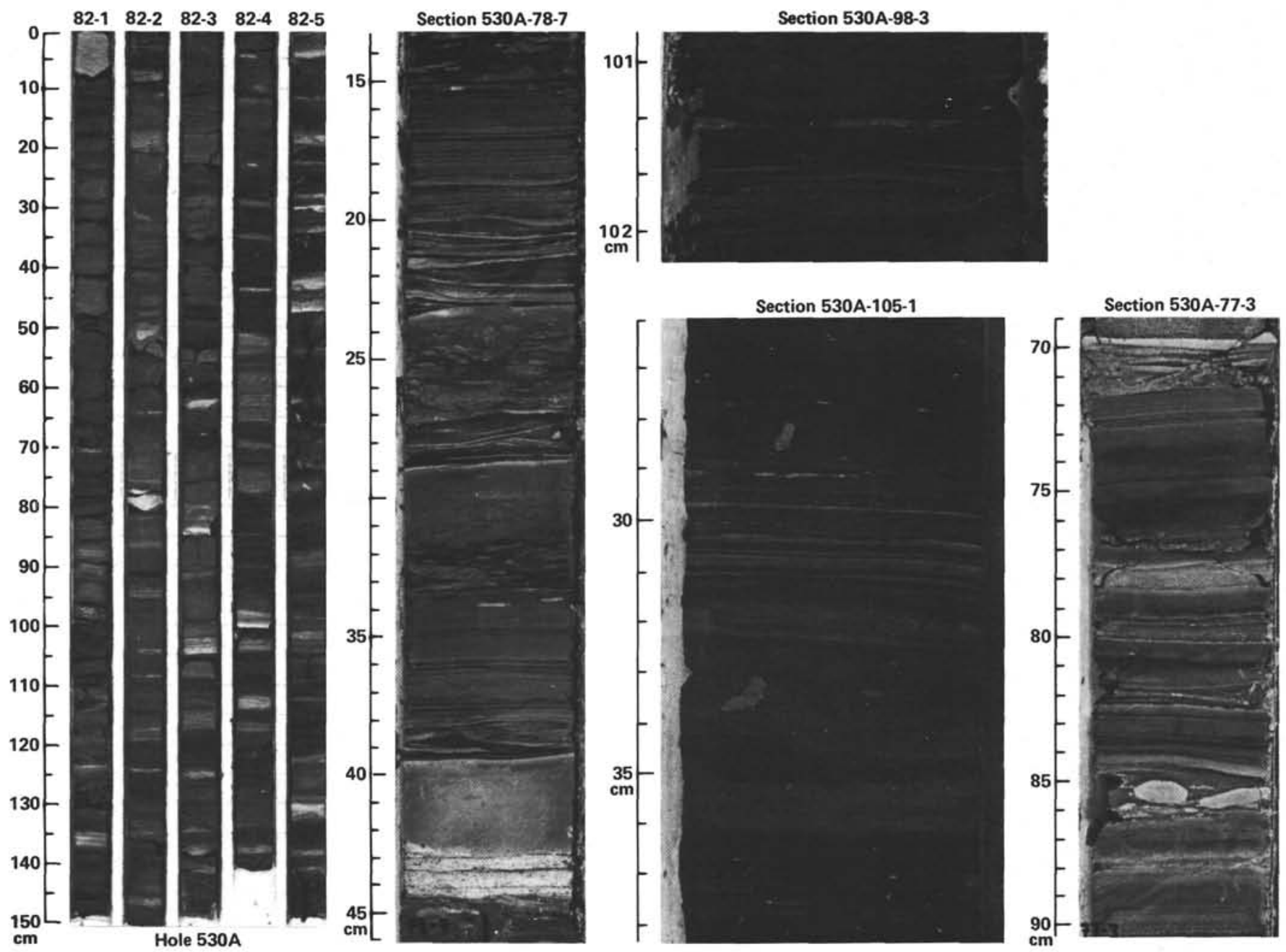

Plate 3. Silt and mud turbidites. (Scale in $\mathrm{cm}$.) Left: Very thin and thin-bedded silt-mud turbidites pass up core into medium-bedded sandstone turbidites (green fan, outer lobe sequence). Center and right: details of fine-grained turbidites. 

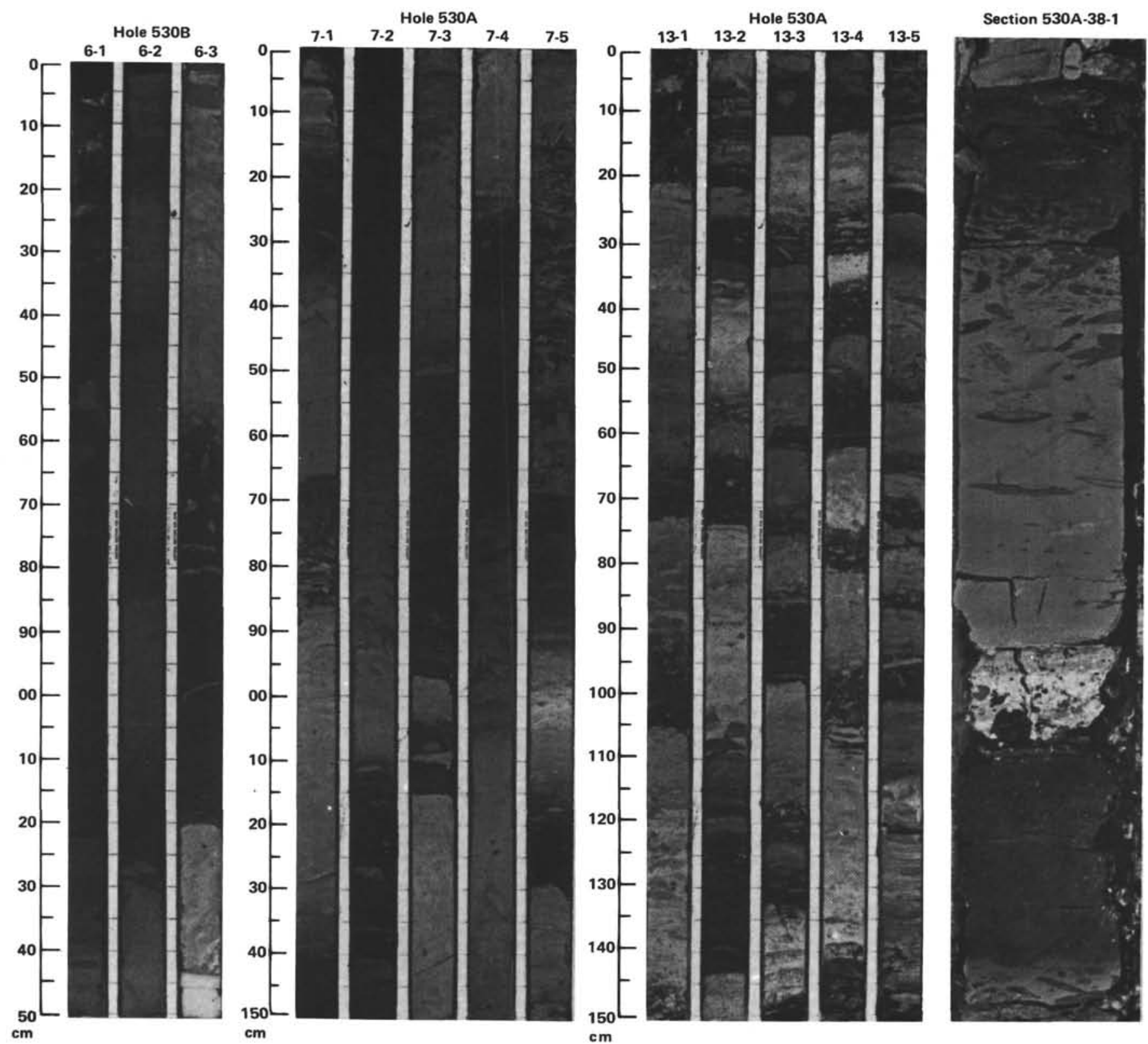

Plate 4. Pelagic turbidites. (Scale in $\mathrm{cm}$.) Narrow core sections show thin to thick-bedded muddy diatomaceous turbidites (dark) interbedded with calcareous pelagic ooze (from brown fan). Right-hand core (width about $7 \mathrm{~cm}$ ) shows pebbly calcarenite grading upwards into calcilutite turbidite (from white fan). 